Check for updates

Cite this: Chem. Commun., 2019, 55, 11143

Received 11th July 2019,

Accepted 18th August 2019

DOI: $10.1039 / c 9 c c 05337 a$

rsc.li/chemcomm

\section{Ubiquitous aluminium contamination in water and amyloid hybrid membranes as a sustainable possible solution $\dagger$}

\author{
Mohammad Peydayesh, (D) a Malvina Pauchard, ${ }^{b}$ Sreenath Bolisetty, ${ }^{\text {ac }}$ \\ Francesco Stellacci iD ${ }^{b}$ and Raffaele Mezzenga (iD *ad
}

\begin{abstract}
We develop a membrane technology based on amyloid fibrils to remove aluminium from water and minimize its exposure to humans. We study aluminium adsorption by amyloid fibrils by evaluating the binding isotherms, the thermodynamics and the effects of different parameters. Amyloid-based membranes demonstrate outstanding removal efficiencies beyond $98 \%$.
\end{abstract}

The elevated amounts of aluminium in water could be considered as a threat for health and survival of human beings and animals. Acid rain mobilizes aluminium from soil to water by acidification of rivers and lakes. ${ }^{1}$ According to WHO, the concentration of aluminium in drinking water after the coagulation process should not exceed 100-200 ppb, but the effect of aluminium in drinking water on Alzheimer's disease, at these or lower concentrations, cannot be entirely dismissed. ${ }^{2,3}$ Besides human bodies, acute aluminium toxicity for fishes in acidic aquatic environments, ${ }^{4}$ as well as, infertility and fractal production of egg shells in wild birds ${ }^{5}$ have also been reported.

Nonetheless, compared to other metals, many question marks, uncertainties and lack of data on aluminium toxicity and exact damage on the human body and other organisms remain to date. For instance, the gastrointestinal aluminium absorption mechanism $^{3}$ and the true body burden of aluminium ${ }^{6}$ have not been fully elucidated, yet. Furthermore, there are many uncertainties related to types of aluminium salt, $\mathrm{pH}$, bioavailability and dietary parameters. ${ }^{3}$

By considering these levels of uncertainty and risk estimation, preventive actions and solutions become of immediate

\footnotetext{
${ }^{a}$ Department of Health Sciences and Technology, ETH Zurich, Schmelzbergstrasse 9, 8092 Zurich, Switzerland. E-mail: raffaele.mezzenga@hest.ethz.ch; Tel: +41446329140

${ }^{b}$ Supramolecular Nanomaterials and Interfaces Laboratory, Institute of Materials, École Polytechnique Fédérale de Lausanne, 1015 Lausanne, Switzerland

${ }^{c}$ BluAct Technologies GmbH, 8092 Zurich, Switzerland

${ }^{d}$ Department of Materials, ETH Zurich, Wolfgang-Pauli-Strasse 10, 8093 Zurich, Switzerland

$\dagger$ Electronic supplementary information (ESI) available: Materials and methods. See DOI: $10.1039 / \mathrm{c} 9 \mathrm{cc} 05337 \mathrm{a}$
}

significance. Typical technologies for aluminium removal from drinking water are reverse osmosis and vapor distillation, which both suffer from high-energy demand ${ }^{7}$ and the need to re-adjust the oligomineral composition prior to water consumption. ${ }^{8}$ Thus, there is a need for more sustainable and efficient approaches for removal of aluminium from drinking water. Here, we focus on minimizing the aluminium exposure from water and beverages using $\beta$-lactoglobulin amyloid fibril based membranes. $\beta$-Lactoglobulin is the principal protein in whey, a by-product of cheese production in the dairy industry. ${ }^{9}$ Amyloid fibrils have excellent interaction and binding capabilities, especially with heavy metals. ${ }^{9,10}$ Although the ability of amyloid fibrils in removing heavy metals is now widely recognized,,$^{9,10}$ their removal performance for lighter metals such as aluminium has not yet been evaluated. To start, the ubiquity of aluminium in diverse water and beverage sources was assessed. The study was performed using a random selection of 29 sources.

The aluminium content of different sources is summarized in Fig. 1 in an anonymized format. As observed, aluminium was detected in all samples. In natural waters, the concentrations were below $100 \mathrm{ppb}$. As acidification of the environment increases the mobilization of aluminium form soil to natural water, is estimated to increase, such as in countries with higher amounts of acid rain. ${ }^{11}$ In this study, two brands of bottled spring water and two brands of purified water were tested. The aluminium concentration in the spring waters was higher than in the purified waters. The lower concentrations of the latter is due to the purification step with reverse osmosis and vapor distillation technologies, ${ }^{7}$ as mentioned on the bottle labels.

Of all the seven tap waters collected in Switzerland, only one had aluminium concentration above $50 \mathrm{ppb}$ and the average concentration for tap water was found to be $29 \mathrm{ppb}$. For six studied coffee capsule brands, the aluminium content was generally higher than for tap waters. The concentrations varied from 24 to $223 \mathrm{ppb}$, depending on the brand and the machine. ${ }^{12}$ For the tea capsules, an alarming aluminium concentration as high as 45 ppm was found. Tea is one of the few plants with the ability to accumulate aluminium, so it is unclear at this stage 


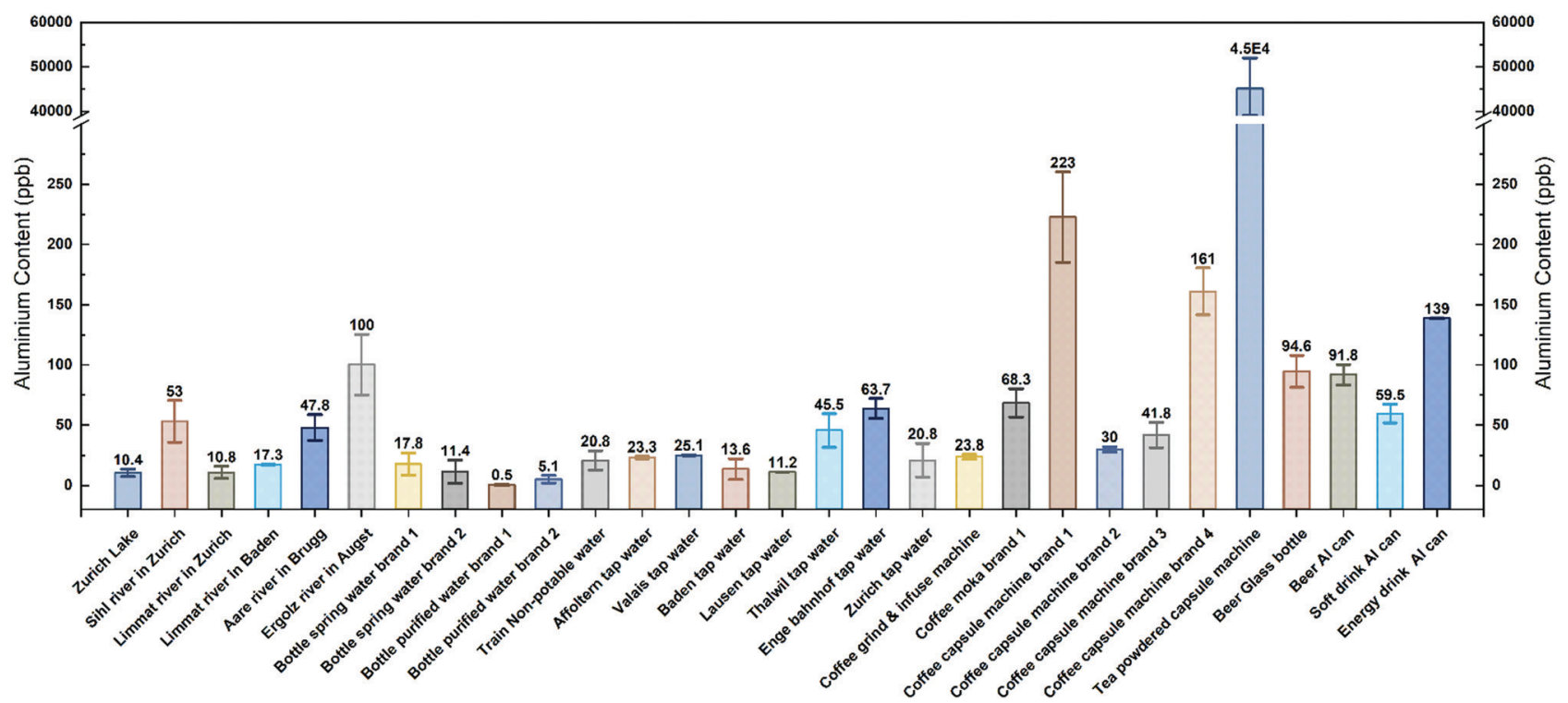

Fig. 1 Occurrence of aluminium in different collected water and beverage sources.

whether the contamination arises from the packaging or the tea leaves themselves. Typically, most of the plants cannot tolerate aluminium toxicity, which is a serious problem in agriculture. ${ }^{13}$ The effect of different packaging materials on the release of aluminium into the samples was further evaluated by measuring the concentration of aluminium in beers from the same company but in two different packaging formats: aluminium can and glass bottle. The concentration in both samples was around $90 \mathrm{ppb}$, which shows a negligible effect of packaging material type on total aluminium content ${ }^{14}$ and rather points to a sourcecontamination.

Furthermore, the aluminium content of soft drinks and energy drinks in aluminium cans was also measured. The aluminium concentration in the energy drink was $139 \mathrm{ppb}$, which was approximately two times more than the amount for the soft drink, that has $60 \mathrm{ppb}$ concentration.

In order to remove aluminium from water using a hybrid amyloid membrane, we first assess the binding performance of aluminium onto $\beta$-lactoglobulin amyloid fibrils (ESI $\dagger$ ). Fig. 2 presents the binding isotherms of $\mathrm{AlCl}_{3}, \mathrm{Al}\left(\mathrm{NO}_{3}\right)_{3}$ and $\mathrm{Al}_{2}\left(\mathrm{SO}_{4}\right)_{3}$, fitted by the approach of Swillens and Motulsky. ${ }^{9}$ For the three salts, by increasing the initial concentration, the adsorbed amounts of aluminium per weight of adsorbent increases.
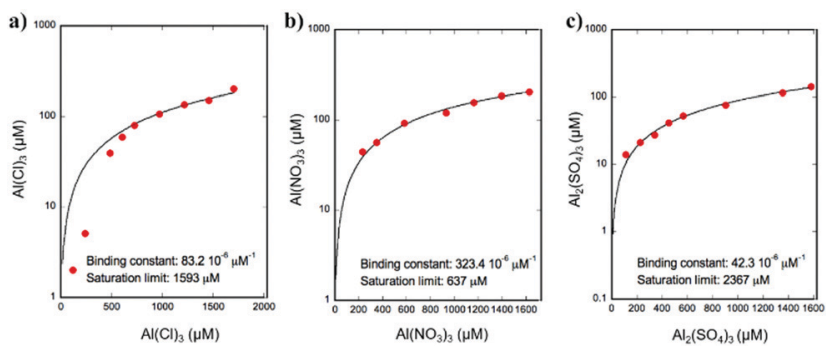

Fig. 2 Fitted binding isotherms of $\mathrm{AlCl}_{3}, \mathrm{Al}\left(\mathrm{NO}_{3}\right)_{3}$ and $\mathrm{Al}_{2}\left(\mathrm{SO}_{4}\right)_{3}$ adsorption with $10 \mathrm{mg}$ amyloid fibrils.
The results indicate that for $\mathrm{Al}\left(\mathrm{NO}_{3}\right)_{3}$, the binding constant $\left(K_{\mathrm{a}}\right)$ of $323.6 \mathrm{M}^{-1}$ is higher than that for $\mathrm{AlCl}_{3}$ having $83.2 \mathrm{M}^{-1}$ and $\mathrm{Al}_{2}\left(\mathrm{SO}_{4}\right)_{3}$ having $42.3 \mathrm{M}^{-1}$. This result shows that amyloid fibrils bind $\mathrm{Al}\left(\mathrm{NO}_{3}\right)_{3}$ ions stronger than the two other salts. Furthermore, the amyloid fibril adsorption saturation limits were 1593, 637 and $2367 \mu \mathrm{M}$ for $\mathrm{AlCl}_{3}, \mathrm{Al}\left(\mathrm{NO}_{3}\right)_{3}$ and $\mathrm{Al}_{2}\left(\mathrm{SO}_{4}\right)_{3}$, respectively. The supramolecular binding of aluminium with amyloid fibrils involves interactions of several amino acid residues. The interaction of aluminium with some amino acids such as ornithine, lysine, aspartic acid, glutamic acid and tyrosine in human blood was reported. ${ }^{15}$ This implies multiple binding constants working synergistically in amyloid fibrils, and highlights the complexity of the binding reaction.

We then studied the effect of $\mathrm{pH}$ on $\mathrm{AlCl}_{3}, \mathrm{Al}\left(\mathrm{NO}_{3}\right)_{3}$ and $\mathrm{Al}_{2}\left(\mathrm{SO}_{4}\right)_{3}$ adsorption from $\mathrm{pH} 2.8$ to $\mathrm{pH} 10$. As observed in Fig. 3, for the three salts, by increasing the $\mathrm{pH}$ from 2.8 to 5 , the adsorption amount $(q)$ increases. Then, $q$ stays constant up to $\mathrm{pH} 7$ and eventually decreases from $\mathrm{pH} 7$ to 10 . The highest adsorption amount was obtained between pH 5 and 7, which corresponds to the application range of $\mathrm{pH}$ in most water treatments. ${ }^{16}$

The $\mathrm{pH}$ affects not only the surface charge of the amyloid fibrils but also the degree of ionization of the aluminium in solution. ${ }^{17}$ The isoelectric point (IEP) of amyloid fibrils is around pH 5. ${ }^{18}$ Complexation of aluminium with hydroxide determines the solubility of aluminium in water and subsequently the efficiency of its chemical reaction. ${ }^{19}$ The distribution of aluminium species in solution $\left(\mathrm{Al}^{3+},[\mathrm{AlOH}]^{2+},\left[\mathrm{Al}(\mathrm{OH})_{2}\right]^{+}, \mathrm{Al}(\mathrm{OH})_{3}\right.$ and $\left.\left[\mathrm{Al}(\mathrm{OH})_{4}\right]^{-}\right)$as a function of $\mathrm{pH}$ was calculated ${ }^{20}$ and depicted in Fig. 3. $\mathrm{Al}^{3+},\left[\mathrm{Al}(\mathrm{OH})_{2}\right]^{+}$and $\left[\mathrm{Al}(\mathrm{OH})_{4}\right]^{-}$are predominant states at $\mathrm{pH}<3.5,4-5$ and $>5.5$, respectively. Between $\mathrm{pH} 5$ and 7 , aluminium solubility decreases as $\mathrm{Al}(\mathrm{OH})_{3}$ is formed, while the other complexes remain soluble in water. ${ }^{19,21}$

At low $\mathrm{pH}$, both the adsorbent and the aluminium species in solution are positively charged, and electrostatic repulsion 


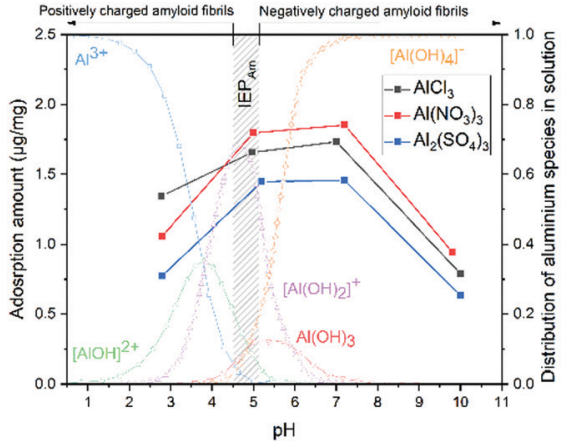

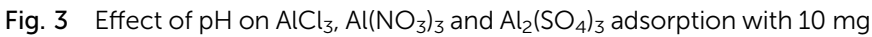
amyloid fibrils.

competes with supramolecular metal-ligand binding interactions, decreasing the adsorption amount. At $\mathrm{pH} 5$ amyloid fibrils are globally neutral. However, locally, amino acids composing the protein are protonated (neutral and positively charged) or deprotonated (negatively charged) depending on their acid dissociation constant. ${ }^{22}$ Thus, by increasing the $\mathrm{pH}$ from 3 to $5, q$ increases due to the increased attractive electrostatic interactions between deprotonated amino acids and cationic aluminium complexes, as well as between protonated amino acids and $\left[\mathrm{Al}(\mathrm{OH})_{4}\right]^{-}$. From $\mathrm{pH} 7$, both the adsorbent and aluminium species are mainly negatively charged and $\left[\mathrm{Al}(\mathrm{OH})_{4}\right]^{-}$has a lower affinity for binding due to the counteracting electrostatic repulsion. By increasing $\mathrm{pH}$ to 10 , in addition to increasing electrostatic repulsion, the concentration of $\mathrm{OH}^{-}$increases from $10^{-7}$ to $10^{-4} \mathrm{~mol} \mathrm{~L}^{-1}$. Thus, $\mathrm{OH}^{-}$ion competition with aluminium to bind on amyloid fibrils leads to a further decrease of the overall adsorption amount. ${ }^{19}$

To elucidate the thermodynamic traits and effect of temperature on aluminium and amyloid fibril interactions, isothermal titration calorimetry (ITC) experiments were run (ESI $\dagger$ ). The ITC results at the three different temperatures are shown in Fig. 4. By applying basic thermodynamic equations, ${ }^{23}$ enthalpy change $(\Delta H)$, dissociation constant $\left(K_{\mathrm{d}}\right)$, the interaction stoichiometry $(n)$, Gibbs free energy $(\Delta G)$ and entropy change $(\Delta S)$ were determined.

For the binding of aluminium with $\beta$-lactoglobulin amyloid fibrils, at all three temperatures, $\Delta H, \Delta G$ and $\Delta S$ values were negative. The negative change in enthalpy indicates that the reaction is exothermic. ${ }^{23}$ In addition, negative values of $\Delta G$ confirm the spontaneous and favourable nature of reaction. ${ }^{24}$ Loss of configurational and/or conformational entropy are reflected by negative $\Delta S$ values. The latter is mainly due to the mobility restriction of the fibril backbone and side chain during metal-fibril complexation. ${ }^{25}$

As observed in Fig. 4, approximately two moles of aluminium could be absorbed by one mole of amyloid fibrils equivalent. $K_{\mathrm{d}}$ is the inverse form of $K_{\mathrm{a}}$ and its high order of magnitude in all temperatures shows the strong binding of aluminium with $\beta$-lactoglobulin amyloid fibrils. By increasing the temperature from 5 to $75^{\circ} \mathrm{C}, K_{\mathrm{d}}$ values increase from $552 \times 10^{-6}$ to $731 \times 10^{-6} \mathrm{M}$. For an exothermic reaction, the Arrhenius law states that by increasing

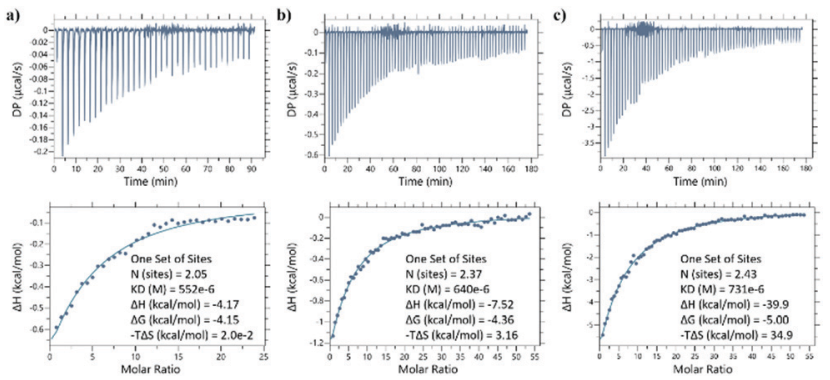

Fig. 4 Fitted binding isotherms of $\left.\mathrm{AlCl}_{3}, \mathrm{Al}_{(} \mathrm{NO}_{3}\right)_{3}$ and $\mathrm{Al}_{2}\left(\mathrm{SO}_{4}\right)_{3}$ adsorption with $10 \mathrm{mg}$ amyloid fibrils.

temperature, $K_{\mathrm{a}}$ decreases, ${ }^{26}$ which confirms the obtained results on the binding constant $v s$. temperature.

Having demonstrated the ability of $\beta$-lactoglobulin amyloid fibrils to bind aluminium, we design amyloid-based membranes to remove aluminium from water and wastewater (ESI $\dagger$ ). The aluminium concentrations before and after filtration are shown in Fig. 5a. As observed, the concentration of aluminium after filtration by amyloid fibril membranes was reduced from $100 \mathrm{ppb}$ to 9.9, 8.6 and $11 \mathrm{ppb}$ for $\mathrm{AlCl}_{3}, \mathrm{Al}\left(\mathrm{NO}_{3}\right)_{3}$ and $\mathrm{Al}_{2}\left(\mathrm{SO}_{4}\right)_{3}$, respectively. For the three salts, there is no significant difference between the concentrations after filtration, and the differences are in the error range of experiments. This indicates that the type and valence of the counter-ions of aluminium salts, i.e. $\mathrm{Cl}^{-}, \mathrm{NO}_{3}{ }^{-}$and $\mathrm{SO}_{4}{ }^{2-}$, and attractive electrostatic forces do not have a significant impact on adsorption efficiency. ${ }^{9}$ The membrane removal efficiencies for $\mathrm{AlCl}_{3}, \mathrm{Al}\left(\mathrm{NO}_{3}\right)_{3}$ and $\mathrm{Al}_{2}\left(\mathrm{SO}_{4}\right)_{3}$ were 90,91 and $89 \%$, respectively. To enhance these removal efficiencies, one has to increase the amount of amyloid fibrils in the membrane, at the expenses of flux. The solution for simultaneous increase of the amyloid fibril amount and
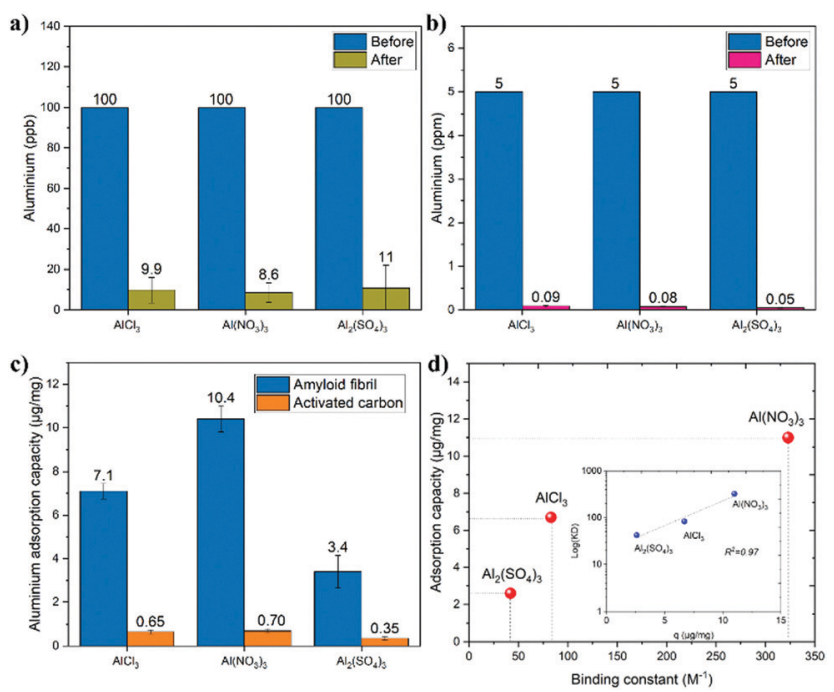

Fig. 5 Concentration of different aluminium solutions before and after filtration through amyloid fibril membranes (a) and through hybrid amyloid fibrilactivated carbon membranes (b), comparison of the relative specific adsorption capacities per mg of amyloid fibrils and/or activated carbon membranes (c) and relation between adsorption capacities and binding constants (d). 
membrane flux can be pursued by adding to the amyloid fibrils porous material, such as activated carbon, to provide higher surface area exchange. The fabrication of hybrid amyloid fibrils-activated carbon membrane and its application for heavy metal removal were already demonstrated and discussed in our previous studies. ${ }^{9,10}$ In what follows, we use commercial hybrid amyloid fibrils-activated carbon membranes based on such a technology ${ }^{9,10}$ (ESI $\dagger$ ). The aluminium concentrations before and after filtration by the hybrid amyloid membranes are presented in Fig. 5b. As observed, for $\mathrm{AlCl}_{3}, \mathrm{Al}\left(\mathrm{NO}_{3}\right)_{3}$ and $\mathrm{Al}_{2}\left(\mathrm{SO}_{4}\right)_{3}$, after filtration the concentration of aluminium from $5 \mathrm{ppm}$ was reduced to $0.09,0.08$ and 0.05 , respectively. These reductions correspond to separation efficiencies of $98.2 \%$ for $\mathrm{AlCl}_{3}, 98.4 \%$ for $\mathrm{Al}\left(\mathrm{NO}_{3}\right)_{3}$ and $99 \%$ for $\mathrm{Al}_{2}\left(\mathrm{SO}_{4}\right)_{3}$.

To elucidate the role of amyloid fibrils and activated carbon in this separation, their respective adsorption capacities were compared as shown in Fig. 5c. As shown in Fig. 5c, for the three salts, the adsorption capacities of activated carbon were between 0.34 and $0.70 \mu \mathrm{g}$ of aluminium per $\mathrm{mg}$ of activated carbon. Amyloid fibril membranes have a higher adsorption capacity compared to activated carbon membranes: 11 times higher for $\mathrm{AlCl}_{3}\left(7.1 \mu \mathrm{g} \mathrm{mg}{ }^{-1}\right), 15$ higher times for $\mathrm{Al}\left(\mathrm{NO}_{3}\right)_{3}\left(10.4 \mu \mathrm{g} \mathrm{mg}{ }^{-1}\right)$ and 10 times higher for $\mathrm{Al}_{2}\left(\mathrm{SO}_{4}\right)_{3}\left(3.4 \mu \mathrm{g} \mathrm{mg}{ }^{-1}\right)$. These results indicate the leading adsorption role of amyloid fibrils in the hybrid membranes. It should be noted that the adsorption capacity measured is a dynamic capacity, evaluated under dynamic flow conditions and not static adsorption. Accordingly, this dynamic capacity is expected to correlate directly with the binding constant, and indeed, in Fig. 5d, the relationship between the amyloid fibril removal capacities and binding constants (from Fig. 2) is presented. As observed and expected, for the salts with higher binding constant, the adsorption capacity is also higher. In addition, the relationship of $\log \left(K_{\mathrm{a}}\right)$ and $q$ is linear with $R^{2}$ of 0.95 .

A water purification sustainable technology must feature, in addition to high removal efficiency, also low cost, energy efficiency and environmental compatibility. ${ }^{27,28}$ The hybrid membranes presented in this work consist of protein fibrils and activated carbon, which both are affordable and environmentally friendly. Furthermore, the filtration process is energy-efficient and could be operated under low-pressure demand and/or gravity driving forces, further highlighting their low environmental fingerprint. These results taken together point at hybrid amyloid-activated carbon membranes as a promising technology for removal of any type of aluminium ions from water streams and soft drinks and may possibly contribute to alleviating the problem of ubiquitous aluminium contamination worldwide.

\section{Conflicts of interest}

Raffaele Mezzenga and Sreenath Bolisetty are inventor of an ETH-related patent.

\section{Notes and references}

1 R. G. Miller, F. C. Kopfler, K. C. Kelty, J. A. Stober and N. S. Ulmer, J. - Am. Water Works Assoc., 1984, 76, 84-91.

2 D. R. C. McLachlan, C. Bergeron, J. E. Smith, D. Boomer and S. L. Rifat, Neurology, 1996, 46, 401.

3 World Health Organization, Aluminum in drinking-water, Background document for development of WHO Guidelines for Drinking-water Quality, Report WHO/HSE/WSH/10.01/13, 2010.

4 C. Exley, J. S. Chappell and J. D. Birchall, J. Theor. Biol., 1991, 151, 417-428.

5 N. E. I. Nyholm, Environ. Res., 1981, 26, 363-371.

6 C. Exley, Environ. Sci.: Processes Impacts, 2013, 15, 1807-1816.

7 Water Quality association, WQA Technical Fact Sheet: Aluminum, 2013.

8 S. Bolisetty, M. Peydayesh and R. Mezzenga, Chem. Soc. Rev., 2019, 48, 463-487.

9 M. Peydayesh, S. Bolisetty, T. Mohammadi and R. Mezzenga, Langmuir, 2019, 35, 4161-4170.

10 S. Bolisetty and R. Mezzenga, Nat. Nanotechnol., 2016, 11, 365-371.

11 W. Barabasz, D. Albińska, M. Jaśkowska and J. Lipiec, Pol. J. Environ. Stud., 2002, 11, 199-203.

12 A. Fraňková, O. Drábek, J. Havlík, J. Száková and A. Vaněk, J. Inorg. Biochem., 2009, 103, 1480-1485.

13 T. P. Flaten, Coord. Chem. Rev., 2002, 228, 385-395.

14 L. Jorhem and G. Haegglund, Z. Lebensm.-Unters. Forsch., 1992, 194, $38-42$.

15 D. Bohrer, P. C. do Nascimento, J. K. A. Mendonça, V. G. Polli and L. M. de Carvalho, Amino Acids, 2004, 27, 75-83.

16 D. Ghernaout, The Best Available Technology of Water/Wastewater Treatment and Seawater Desalination: Simulation of the Open Sky Seawater Distillation, 2014.

17 S. Abadian, A. Rahbar-Kelishami, R. Norouzbeigi and M. Peydayesh, Res. Chem. Intermed., 2015, 41, 7669-7681.

18 Y. Cao, S. Bolisetty, G. Wolfisberg, J. Adamcik and R. Mezzenga, Proc. Natl. Acad. Sci. U. S. A., 2019, 116, 4012.

19 C. T. Driscoll and R. D. Letterman, Environmetrics, 1995, 6, 287-305.

20 A. Sarpola, The Hydrolysis of Aluminium: A Mass Spectrometric Study, University of Oulu, 2007.

21 P. T. Srinivasan, T. Viraraghavan and K. S. Subramanian, Aluminium in drinking water: An overview, 1999.

22 J.-M. Jung, G. Savin, M. Pouzot, C. Schmitt and R. Mezzenga, Biomacromolecules, 2008, 9, 2477-2486.

23 P. Saha and S. Chowdhury, in Thermodynamics, ed. M. Tadashi, IntechOpen, 2011, ch. 16, pp. 349-364, DOI: 10.5772/13474.

24 P. Bharmoria and A. Kumar, Biochim. Biophys. Acta, Gen. Subj., 2016, 1860, 1017-1025.

25 G. P. Brady and K. A. Sharp, Curr. Opin. Struct. Biol., 1997, 7, 215-221.

26 Y. Tang, N. Widjojo, G. M. Shi, T.-S. Chung, M. Weber and C. Maletzko, J. Membr. Sci., 2012, 415-416, 686-695.

27 C. Gong, S. Sun, Y. Zhang, L. Sun, Z. Su, A. Wu and G. Wei, Nanoscale, 2019, 11, 4147-4182.

28 X. Yu, S. Sun, L. Zhou, Z. Miao, X. Zhang, Z. Su and G. Wei, Nanomaterials, 2019, 9(2), 276-287. 